\title{
RELASI ETIKA PERJANJIAN LAMA DENGAN ETIKA GLOBAL HANS KÜNG
}

\begin{abstract}
Abstrak
Etika global yang diusulkan oleh Hans Küng berdasarkan Yesus Kristus yang terdapat dalam Injil. Esensinya adalah bagaimana memanusiakan manusia menjadi manusia, yaitu dengan memerjuangkan hak asasi manusia yaitu hak yang melekat di dalam diri manusia itu sendiri. Perjuangan atas kemanusiaan tersebut ternyata berakar dari Perjanjian Lama, di mana landasan dari perjuangan Yesus adalah seruan dari para nabi dalam Perjanjian Lama, yaitu untuk memerjuangkan hak asasi manusia, sehingga manusia memeroleh keadilan dalam kehidupannya.
\end{abstract}

Kata Kunci: Etika global, kemanusiaan

\section{Pendahuluan}

Pertanyaan yang timbul adalah apakah ada perbedaan antara etika Perjanjian Lama dan etika global Hans Küng? Sebab, dasar atau fondasi dari etika global Küng adalah Perjanjian Baru yaitu berdasarkan Yesus Kristus. Hal ini merupakan penelitian penulis untuk melihat korelasi antara etika Perjanjian Lama dan etika global Küng.

Penulis melihat bahwa ada korelasi atau hubungan antara etika Perjanjian Lama dengan etika global Küng. Sebab, etika global fondasinya adalah etika Perjanjian Lama, meskipun Küng tidak menyatakannya dalam tulisannya, sebab fokusnya adalah pada kehidupan Yesus Kristus. Oleh sebab itu, penulis akan mendeskripsikan dalam paper ini korelasi atau hubungan antara etika Perjanjian Lama dan etika global. 


\section{ETIKA PERJANJIAN LAMA}

Konteks atau situasi bangunan etika dalam Perjanjian Lama adalah dalam situasi ancaman dari negara-negara tetangga sekitar Israel atau Timur Dekat Kuno, ketidakamanan, serangan dari negara luar, bahkan dari dalam bangsa Israel itu sendiri. Oleh sebab itu, di bawah ini akan dideskripsikan etika dalam Perjanjian Lama.

\section{Penindasan dalam Perjanjian Lama}

Thomas D. Hanks menyatakan bahwa dalam leluhur bangsa Israel banyak mengalami bentuk penindasan dari negara tetangga mereka, seperti penjajahan, perampokan, peperangan yang dialami, perbudakan di Mesir. Hal ini mengakibatkan kemiskinan yang dialami oleh orang Israel $^{1}$. Salah satu kata penindasan adalah oppression Humiliates_'anah. Anah mengekspresikan sesuatu yang merusak psikologis akibat penindasan. Kata ini digunakan 82 kali dalam Perjanjian Lama. Kata ini dapat diartikan sebagai "tertindas," "merusak kehormatan/menghina." Dalam bahasa Arab, artinya adalah "tunduk2". Anah merupakan kata pertama yang digunakan dalam Perjanjian Lama untuk mengekspresikan penindasan (Kej.15:13), di mana Abraham sebagai orang asing, imigran pertama yang tidak memiliki tanah; perbudakan; akibatnya ditekan, memiliki beban yang sangat berat. Kejadian 1:1-7 mengatakan bahwa Israel menjadi miskin karena negara yang besar telah menindas mereka. Ini merupakan dosa dari penindas mereka. Keluaran 20: 22-23:33, yaitu pengalaman pembebasan Israel merupakan paradigma pembebasan. Anah berhubungan dengan kemiskinan dan penindasan, yaitu imigran, janda, dan anak yatim piatu. Allah akan menghukum penindasan terhadap orang miskin, sebab Allah murka terhadap penindasan. Mazmur 94, pararel antara penindasan dan kemiskinan, yang mengakibatkan fisik dan psikologis. Dalam pemikiran Ibrani, kemiskinan

${ }^{1}$ Thomas D. Hanks, God So Loved the Third World (New York: Orbis Books, 1983), 1-10.

2 Ibid., 15-17. 
digambarkan sebagai orang yang tidak memiliki pertahanan/perlindungan dalam tatanan sosial, seperti imigran, janda dan anak yatim piatu ${ }^{3}$.

Penindasan (secara kekerasan baik fisik, mental) yang terdapat di dalam Alkitab menurut Hanks mengakibatkan kemiskinan secara sosialekonomi, ketidakadilan sosial, kekerasan fisik, mental ${ }^{4}$. Hal ini dilakukan bukan hanya individu, melainkan secara institusional, sehingga mengakibatkan penderitaan bagi orang yang lemah, tidak mampu dan orang miskin (janda, anak yatim piatu, imigran), di mana mereka tidak memiliki kekuatan untuk melawan dan tidak memiliki tempat perlindungan.

Oleh sebab itu, Leon Epzstein mengatakan bahwa dalam konteks penindasan, penjajahan, ketidakamanan inilah muncul konsep hukum, peraturan secara khusus adalah konsep keadilan dalam Perjanjian Lama (pada masa nomad) ${ }^{5}$. Akan tetapi, pada masa monarki justru hal penindasan ini dilakukan oleh sistem institusional, seperti raja, pejabat, hakim, imam, bangsawan, orang kaya dan yang lainnya ${ }^{6}$. Namun, serangan dari luar atau bangsa lain juga menyertainya.

\section{Keadilan: Etika dalam Perjanjian Lama}

Dalam situasi penindasan, tekanan, penderitaan yang dialami oleh Israel tersebut, maka etika yaitu keadilan sangat diutamakan dalam Perjanjian Lama menurut Rogerson 7 . Karena, menurut Bruce C. Birch

\section{${ }^{3}$ Ibid.}

${ }^{4}$ Ibid.

${ }^{5}$ Leon Epzstein, Social Justice in the Ancient Near East and the People of the Bible (London: SCM Press, 1986), 85-89.

6 Ibid.

7 John W. Rogerson, "Discourse and Biblical Ethics" dalam John W. Rogerson; Margareth Davies; dan M. Daniel Carrol R (eds), The Bible in Ethics (Sheffield: Sheffield Academic Press, 1995), 17-26. 
bahwa Allah sendiri yang merasakan penderitaan umat-Nya (Kel. 3:7-8) . Baginya, Keluaran 3:7-8 menyatakan bahwa karakter Allah yang mendengar dan mengetahui (2:24-25). Ini merupakan karakter Allah. Namun, mengetahui/know dimengerti sebagai relasional dan berpartisipasi dalam relasi tersebut. Jadi, kata mengetahui dihubungkan dengan penderitaan Israel. Allah sendiri yang memilih untuk ikut terlibat dalam penderitaan Israel. Inilah yang menjadi karakter Allah, yaitu mengidentifikasikan diri-Nya dengan penderitaan Israel dan menjadi dasar dari tindakan-Nya?

Dalam konteks atau situasi inilah muncul peraturanperaturan/hukum dalam Perjanjian Lama, yaitu keadilan. Kata yang digunakan dalam kata keadilan tersebut adalah Tsaq diasosiasikan dengan kesetiaan terhadap hukum dan moralitas. Mishphat selalu digunakan terhadap hukum, artinya adalah keadilan. Akar katanya adalah shapat yang artinya adalah hakim. Misphat menandakan hukum atau adat, tetapi lebih diarahkan kepada badan hukum, lebih mengarah kepada undang-undang. Jadi, ia sesuatu yang kewajiban dan sangat penting: suatu peraturan agama yang disesuaikan dengan kehendak Allah ${ }^{10}$.

Tsedeq atau tsedaqa: diterjemahkan sebagai adil, yang menandakan lebih daripada keadilan dalam pengadilan. Kedua kata ini lebih mengarah kepada konsep etika yang berhubungan pada kehidupan sosial dan legal umat Allah. Kata ini lebih menekankan fenomena sosial mengenai hubungan antara duan kelompok. Dalam Israel kuno, tindakan seseorang

${ }^{8}$ Bruce D. Birch, "Divine Character and the Formation of Moral Community in the Book of Exodus", dalam John W. Rogerson; Margareth Davies; dan M. Daniel Carrol R (eds), The Bible in Ethics (Sheffield: Sheffield Academic Press, 1995), 119-136.

\section{${ }^{9}$ Ibid.}

${ }^{10}$ Epzstein, Sosial Justice, 45-49. 
tidak dihakimi berdasarkan norma yang abstrak dan absolut, melainkan berdasarkan fungsi konkret dan relasi manusia ${ }^{11}$.

H.H. Schmid dalam Epzstein menyatakan bahwa kata $t s d q$ sebagai lingkaran hukum, hikmat, kesuburan/alami, perang/kemenangan atas musuh, pengorbanan/ibadah dan kesetiaan. Sementara itu, Andre Neher menyatakan bahwa arti kata tersebut adalah pemujaan, respek, legalitas, kasih dan kemurahan hati. Ini merupakan simbol kebajikan dan kejujuran. Ini menunjukkan keadilan dan hukum yang baik ${ }^{12}$.

Maka tidak heran bila seorang ahli sosiologi C. Van Leeuwen dalam Epzstein melihat secara faktor sosiologi bahwa perjuangan para nabi, dan pemazmur untuk keadilan sosial dalam membuat undang-undang atau hukum ${ }^{13}$. Prinsip keadilan sosial (melampaui kondisi sejarah) adalah tidak mencari persamaan keadilan bagi semua, tetapi keadilan khusus bagi orang miskin dan orang lemah. Misalnya perlawanan dalam Perjanjian Lama yang menjual anak-anaknya menjadi budak karena hutang. Senada dengan J. Pedersen dalam Epzstein mengungkapkan bahwa bagi Israel yang terpenting adalah keadilan (bagi Arab hal yang terpenting adalah kehormatan). Jadi, kemanusiaan atau humanisme menjadi esensi/hakikat dan pusat dari rohnya Israel ${ }^{14}$. Contohnya adalah Ayub merupakan roh/jiwa dari orang Israel, bahwa ia menerima segala kehilangan harta benda maupun penyakitnya yang dideritanya, tetapi ia menuntut dan memerjuangkan keadilan dan tidak mau dipisahkan dari keadilan. Maka dalam pandangan Israel, keadilan bukan hanya nilai pribadi atau individu, melainkan esensi dari kesehatan sosial. Manusia yang adil adalah totalitas keseluruhan, di mana ia membuat covenant. Keadilan dan kebenaran merupakan ekspresi dari ciri-ciri budaya Israel
11 IbId., 47.
12 IbId., 48.
${ }^{13}$ Ibid., 50-54.
${ }^{14}$ Ibid. 
kuno yang menjadi hak dan harus diterimanya ${ }^{15}$. Oleh sebab itu, di bawah ini akan dijelaskan konsep keadilan menurut Perjanjian Lama menurut Epzstein. ${ }^{16}$

\section{Keadilan masa semi-nomaden ${ }^{17}$}

Pada masa semi-nomad Abraham-Yakub, mereka berusaha memerjuangkan spirit kemanusiaan/humanis, sehingga mereka dapat bertahan hidup dari kerasnya alam maupun masyarakat dan bangsa sekitarnya untuk memertahankan dirinya. Oleh sebab itu, semangat solidaritas dan keadilan dalam atmosfir kemerdekaan dikembangkan dalam hidupnya. Menurut paradigma Israel, semua manusia diciptakan oleh Allah dalam gambar dan rupa-Nya, mereka memiliki keuntungan dan memiliki tanggungjawab yang sama. Inilah dasar hukum egaliter dalam Perjanjian Lama yang berbeda dengan hukum negara lain. Misalnya, hukum gigi ganti gigi (Kel.21:23-25) adalah sama bagi semua Israel kecuali budak.

Di sisi lain, nenek moyang Israel harus menerima atau menyambut kelompok lain yang datang padanya dengan ramah. Mereka harus saling tolong menolong. Kekayaan secara materi adalah hal yang kedua, tetapi yang terpenting adalah kemurahan hati, keramahan. Tidak ada tentara atau penjaga keamanan dalam padang gurun, oleh sebab itu mereka bersama-sama menghukum penjahat. Hal inilah yang mendukung solidaritas untuk melindungi anggota yang tertindas.

Mereka juga harus berdagang atau barter barang (mereka peternak). Dalam pertukaran tersebut, transaksi mereka harus jujur. Kitab Imamat mengatakan agar adil pengadilan, dan juga jujur dalam berdagang, dengan timbangan yang jujur (19:35; Ul.25:13). Jadi, keseimbangan

\footnotetext{
15 Ibid.

${ }^{16}$ Epzstein, Social Justice, 1-178.

${ }^{17}$ Ibid., 85-89.
} 
merupakan instrumen yang sangat esensial dan menjadi simbol untuk keadilan.

\section{Keadilan pada masa nabi-nabi ${ }^{18}$}

Nubuatan para nabi merupakan hal yang sangat penting dalam kehidupan agama, politik dan struktur sosial Israel. Mereka menyatakan bahwa ibadah kepada Yahweh harus disertai dengan perbuatan. Hal inilah yang diserukan oleh Amos, apabila Israel beribadah kepada Yahweh, tetapi masih melakukan ketidakadilan, maka ini adalah penghujatan terhadap-Nya (5:21-24). Ia adalah saksi dan korban dari ketidakadilan tersebut. Ia mengkritik segala bentuk eksploitasi (4:1). Jadi, penekanan para nabi adalah sisi kemanusiaan (misalnya keadilan) yang terjadi pada kekinian/present di mana mereka berada, sehingga ini menjadi prinsip Yudaisme ${ }^{19}$.

Pemikiran Yahudi bukanlah dualisme, melainkan kebenaran seluruh bidang adalah kesatuan. Pemikirannya berusaha menyatukan fisik/materi dengan spiritual, konkret dan idealisme, bukan asketis ${ }^{20}$. Mereka tidak berusaha menghilangkan kekayaan/materi, menghilangkan hak miliki pribadi. Para nabi membuktikan bahwa musuh bukanlah hanya menghancurkan moralitas, tetapi juga yang melemahkan ekonomi. Bagi para nabi, krisis ekonomi dan sosial terjadi akibat kurangnya keseimbangan. Hal inilah yang diserang oleh para nabi, di mana keuntungan hanya dimiliki oleh orang kaya, penguasa, dan distribusi kekayaan yang tidak seimbang karena ketamakan orang kaya yang didukungan oleh penguasa. Hal inilah yang perlu dikontrol. Menurut Graham dalam Epzstein, para nabi memberitakan kebaikan, kehormatan, kepercayaan, kesetiaan, kelakuan yang baik, keadilan seharusnya menjadi motif dalam mencari keuntungan dalam kerangka disiplin moral ${ }^{21}$. Jadi,
18 Ibid., 90-103.
19 Ibid.,93-95.
${ }^{20}$ Ibid., 98-100.
${ }^{21}$ Ibid., 93. 
para nabi menyerang orang kaya yang jahat, melindungi orang miskin, lemah, tertindas; menyerang hak istimewa raja. Maka, kunci nasib orang Yahudi adalah protes melawan kejahatan dan membela keadilan.

Oleh sebab itu melalui para nabi, Philips R. Davies menyatakan bahwa mereka sangat memerhatikan etika di di Israel yaitu mengenai penindasan terhadap orang-orang yang lemah, terpinggirkan, kurang mampu dan tidak memiliki kekuatan apapun untuk memertahankan dirinya $^{22}$. Maka, mereka meneriakkan dan memerintahkan untuk memerjuangkan serta menegakkan keadilan dan kebenaran (seperti dalam hikmat Amsal).

\section{Keadilan sosial dalam Pentateuch ${ }^{23}$}

\section{Hukum kuno dalam Perjanjian Lama ${ }^{24}$}

Keadilan dalam hukum kuno Israel adalah merupakan suatu kehidupan (bukan hanya ekonomi dan politik), dan bukan sebatas hukum (U1.16:20). Hal ini merupakan sesuatu yang diusahakan secara seimbang. Misalnya dalam pengadilan tidak boleh bersaksi dengan palsu atau berdusta, pengadilan harus jujur, tidak korupsi (Kel.23:2; Im.19:15; Ul.1:17; 10:17;). Dengan demikian dalam Perjanjian Lama, hukum keadilan adalah sama seperti hukum fisik yaitu memerintah di dalam hati umat manusia, tanpa diskriminasi kelas sosial, nasional dan hak istimewa yang transenden (Ul.6:4).

\section{Memelihara/memerjuangkan orang miskin ${ }^{25}$}

22Philips R. Davies, "Ethics and the Old Testamen" dalam John W. Rogerson; Margareth Davies; dan M. Daniel Carrol R (eds), The Bible in Ethics (Sheffield: Sheffield Academic Press, 1995), 164-173.

${ }^{23}$ Epztein, Social Justice, 104-133.

24 Ibid.

${ }^{25}$ Ibid., 105. 
Perjanjian Lama menyatakan bahwa orang miskin harus diminimalkan di bangsa Israel. Jurang antara orang kaya dan miskin tidak boleh sangat lebar. Oleh sebab itu, perlindungan terhadap orang miskin merupakan suatu bentuk kesalehan dari kesalehan Israel tradisional ${ }^{26}$.

Untuk mengatasi hal tersebut, hukum Covenant memerintahkan untuk memberikan perlindungan kepada orang miskin (Kel.23:6) ${ }^{27}$ : 1) tidak membungakan uang kepada orang miskin karena makanan (Kel.22:25); 2) meninggalkan sedikit hasil panen kepada orang miskin (Kel.23:10). Demikian juga dengan hukum Deuteronomi yang menyatakan untuk mengurangi kemiskinan di tengah-tengah anugerah Allah yang besar di Israel (Ul.15:4). Mereka harus saling membantu/solidaritas terhadap orang miskin (Ul.15;11). Kitab Imamat menyatakan bahwa kekudusan hidup harus dipraktekkan atau aplikasikan dalam membantu dan solidaritas terhadap orang miskin/sesama (Im.15:9).

\section{Melindungi janda dan anak yatim piatu ${ }^{28}$}

Janda dan anak yatim piatu merupakan orang-orang yang rentan terhadap kejahatan dan penindasan, karena tidak dapat melindungi diri mereka sendiri. Janda kehilangan suami yang melindunginya, serta ia tidak memeroleh warisan, sebab anak dan pihak dari keluarga laki-lakinya yang mewarisi hartanya. Demikian juga dengan anak yang telah ditinggal mati oleh orang tuanya, di mana orang tuanya meninggalkan hutang,

26 Pada ada masa kerajaan pengaruh Kanaan, Baal, yang menuntut pajak yang tinggi, bunga hutang yang tinggi, gedung/istana yang mewah, kekuasaan pejabat yang tidak seimbang dan penyalahgunaan kekuasaan tanpa ada hukuman, krisis karena perang, mengakibatkan perbedaan antara orang kaya dan miskin terlalu besar.

$$
\begin{aligned}
& { }^{27} \text { Ibid., 109-110. } \\
& { }^{28} \text { Ibid., 113-115. }
\end{aligned}
$$


maka anaknya akan menanggung hutang tersebut. Anak tersebut menjadi budak, bahkan dapat untuk dijual.

Maka, Hukum Covenant melarang untuk menindas janda dan anak yatim piatu (Kel.22:21-23), sehingga mereka harus dilindungi. Demikian juga dengan hukum Deuteronomy yang menyatakan bahwa janda dan anak yatim harus dilindungi, karena mereka memiliki hak dari Allah dan umat-Nya, serta mereka harus menerima keadilan (Ul.24:17). Ladang yang dipanen tidak boleh diambil semua, karena untuk janda dan anak yatim piatu (Ul.14:28; 26:13).

\section{Perlindungan terhadap orang asing ${ }^{29}$}

Bukan hanya anak yatim piatu, janda yang perlu dilindungi, melainkan juga orang asing yang tinggal di Israel. Misalnya adalah tawanan perang, dan imigran, meskipun mereka tidak memiliki status istimewa seperti orang Israel. Mereka biasanya memiliki ekonomi yang lemah dan miskin. Alasannya adalah Israel dahulu adalah orang asing di Mesir (Kel. 23:9), oleh sebab itu mereka harus bermurah hati kepada orang asing/pendatang.

Oleh sebab itu, Hukum Covenant menyatakan bahwa orang asing/pendatang harus diperlakukan secara manusiawi. Mereka juga dapat menikmati sepersepuluhan dari tiga tahun (U1.24;29), dan juga dapat memungut hasil ladang yang ditinggalkan bagi orang janda dan anak yatim (Ul.24:19-21). Hukum Kekudusan/Holiness menambahkan bahwa mereka juga dapat menikmati tahun sabbat (Im.25:6). Hal yang menarik adalah mereka harus dikasihi sama seperti mengasihi dirinya sendiri (Im.19:22) ${ }^{30}$.

\footnotetext{
${ }^{29}$ Ibid, 115-117.

${ }^{30}$ Ibid.
} 


\title{
Menghormati orang yang bekerja/buruh ${ }^{31}$
}

Bangsa Israel mengalami masa penjajahan Assyrian, sehingga mereka mengalami kesulitan ekonomi sangat besar. Mereka harus membayar pajak yang cukup tinggi dan membiayai hidup sehari-hari. Akibatnya mereka berhutang, dan bunganya cukup tinggi. Maka, mereka harus menjual harta, rumah, tanahnya. Oleh sebab itu, untuk mengatasi hidup yang sangat berat tersebut, mereka harus bekerja harian agar mendapat upah. Oleh sebab itu, Deuteronomy mengatakan agar tidak menahan upah dari pada pekerja atau buruh, karena ini adalah dosa dan kejahatan di mata Allah (Ul.24:14-15). Imamat mengatakan agar tidak menindas dan mencuri tetangga, dan menahan upah buruh (Im.19;13), bahkan Hukum Kekudusan memerintahkan untuk membagikan keuntungan kepada pekerja pada saat tahun sabbat (Im.25; 6).

\section{Budak harus dilindungi ${ }^{32}$}

Hukum mengenai perbudakan dalam Perjanjian Lama adalah sangat humanisme dan untuk melindungi para budak. Misalnya adalah hukum Kekudusan melarang perbudakan di antara orang Israel itu sendiri. Sedangkan Deuteronomy membatasi dan memerlakukan budak secara manusiawi. Hukum Covenant menyatakan setelah 6 tahun melayani, maka tahun ke tujuh ia harus dibebaskan (Kel.21:2); budak juga dapat dibebaskan bila sudah menikah dan membawa serta keluarganya. Deuteronomy juga menyatakan kehidupan keluarga budak tidak boleh dicampuri oleh tuannya.

Di sisi lain, seorang budak yang telah lari dari tuannya, maka ia harus dilindungi dan tidak boleh ditindas oleh tuannya atau orang lain (U1.23:15). Hukum Holiness tidak melarang orang asing untuk memiliki budak, tapi bila mereka memiliki budak orang Israel, maka ia keluarganya harus menebusnya (Im.25:48) dan ia harus dibebaskan pada tahun

\author{
${ }^{31}$ Ibid, 118. \\ 32 Ibid.,119-124.
}


ketujuh (Im.25:54). Menurut Walter Houston, ketika budak sudah dibebaskan, tuannya juga harus memberikan sedikit harta kepada budak tersebut dan budak juga harus diperlakukan seperti saudara ${ }^{33}$.

Perbudakan sebenarnya dibatasi, bahkan dilarang di Israel, tapi masih diperkenankan dan harus diperlakukan manusiawi. Karena, mereka dahulu juga adalah budak di Mesir dan Allah membebaskan mereka.

\section{Larangan untuk membungakan uang ${ }^{34}$}

Orang Israel yang memiliki hutang (kesukaran hidup) telah mengakibatkan kehilangan tanah, rumah, keluarga, perbudakan. Maka, Perjanjian Lama melarang untuk untuk mendukung orang miskin (Kel.22:24; 23:20). Hal ini harus diterima oleh orang asing yang tinggal di Israel, dan dilarang di antara orang Israel. Karena, kasih terhadap saudara-saudaranya dan takut akan Allah. Sebagai bangsa terpilih, mereka harus menerima hukum solidaritas.

Walter Houston mengatakan bahwa peraturan yang terdapat dalam Kode Deuteronomy adalah untuk melindungi dan memerhatikan orang miskin dan orang yang terpinggirkan di dalam masyarakat ${ }^{35}$. Ulangan 15:1-18, menyatakan keadilan sosial dengan tidak boleh membungakan uang (ayat 3). Tujuannya adalah untuk melindungi dan menolong orang yang membutuhkan. Di dalam komunitas Israel harus menganggap sesamanya sebagai saudara, dan mereka harus memerlakukan tetangganya sebagai saudara'. Hal ini ditanamkan di dalam dalam hati mereka, karena mereka telah dibebaskan oleh Allah dari Mesir. Kata

33 Walter Houston, “ You shall Open Your Hand to Your Needy Brother: Ideology and Moral Formation in Deuteronomy 15:1-18, dalam Social Justice in the Ancient Near East and the People of the Bible. (eds) Leon Epzstein (London: SCM Press, 1986), 296-315.

${ }^{34}$ Epzstein, Social Justice, 124-128.

${ }^{35}$ Houston, You shall Open Your Hand, 299. 
persaudaraan atau 'brotherhood'36: 1) dikembangkan menjadi bangsa keseluruhan, dan secara implisit adalah untuk membela saudara; 2) apakah mereka saudara kandung atau bukan, mereka dengan murni memerlakukan saudaranya dengan kemurahan hati, bukan dengan hati yang keras. Kata brotherhood secara etika merupakan pusat dari Ulangan 15:1-18, sebagai ekspresi tanggungjawab orang Israel terhadap komunitas mereka atau sesama, apakah saudara, klan, suku ${ }^{37}$. Orang Israel juga tidak boleh memaksa uangnya untuk dikembalikan. Hal ini bukan untuk keuntungan pribadi, tetapi untuk kebutuhan saudaranya yang membutuhkan.

\section{Tahun Sabat ${ }^{38}$}

Sabbath menurut kitab Kejadian merupakan hati ketujuh, di mana Allah berhenti menciptakan, Keluaran 16:23 menuliskan bahwa hari ketujuh adalah perayaan (20:8-10). Sisi kemanusiaan pada Sabbath ini adalah sangat besar, di mana yang diperhatikan bukan hanya sisi fisik, yaitu berhenti bekerja, tetapi juga memerhatikan aspek spiritual. Manusia harus beribadah dan menyembah Allah, karena telah diselamatkan dan

36 Ibid., 304-306.

37 Ada tiga hal yang penting dari ayat ini: 1) fokus di sini adalah saudara/brother; 2) pengulangan kata, hati, tangan, mata (konsentrasi pada tubuh), artinya adalah menunjukkan kedekatan relasi, yaitu saudara/brother adalah orang yang terdekat, secara emosi; 3) secara religius, mengancam orang miskin, maka seruan orang miskin tersebut akan sampai kepada Allah, seperti yang terdapat dalam kitab Covenant (Kel.22:23, 27-28). Jadi, asumsinya adalah bukan dengan revolusi sosial, melainkan dengan panggilan untuk revolusi moral untuk mengubah masyarakat, dan untuk menghilangkan eksplositasi dalam masyarakat.

38 Epzstein, Social Justice, 128-133. 
dibebaskan dari penindasan. Selanjutnya adalah sebagai peringatan akan keluarnya Israel dari Mesir (U1.5:15) ${ }^{39}$.

Hal yang unik lagi adalah Allah alam dan manusia juga terjadi keselarasan, yaitu alam harus diperhatikan, dijaga, dan dirawat, di mana alam pada tahun sabbath tidak boleh ditanami, sehingga istirahat dan juga hasil yang keluar dari alam tersebut dapat diambil oleh orang miskin. Demikian juga dengan hewan, harus berhenti bekerja sama seperti manusia.

Di sisi lain, pada tahun ini juga ada pembebasan budak setelah 6 tahun (Kel.21:2) yang diatur dalam tahun sabbath (Kel.23:11; Im.23:3). Sementara itu, tahun Yubelium adalah sabbathnya hari sabbath atau tahun super sabbath, yaitu untuk transformasi distribusi tanah yang tidak merata atau tidak adil ${ }^{40}$. Ini merupakan restorasi hak milik tanah yang telah dijual (Im.25:11). Sebab, tanah adalah hak milik Allah, jadi mereka hanya memiliki sementara (Im.25;13). Karena, mereka telah dibebaskan dari Mesir, dan tanah yang mereka duduki di Kanaan tidak dapat dimiliki selamanya.

Bagaimanakah dengan etika Hans Küng? Di bawah ini, penulis akan mendeskripsikan etika global Küng, yaitu untuk dapat melihat relasi antara etika Perjanjian Lama dengan etika global Küng.

\section{ETIKA GLOBAL HANS KÜNG}

Etika global merupakan suatu etika minimalis yang berisi konsensus bersama, kritis terhadap diri sendiri, yang berhubungan dengan realitas, yang dapat dimengerti dengan bahasa sehari-hari dan juga berasal dari fondasi agama ${ }^{41}$, di mana Golden Rule dari etika adalah jangan

\section{${ }^{39}$ Ibid.}

40 Ibid.

${ }^{41}$ Hans Küng dan Helmut Schmidt (eds), A Global Ethic and Global Responsibilities: Two Declarations (London: SCM Press, 1998), 56-57. 
memerlakukan manusia secara tidak manusiawi dan yang telah menjadi Golden Rule dari etika global ini adalah: 'Memerlakukan orang lain, seperti diri sendiri atau Apa yang Anda ingin lakukan terhadap diri sendiri, lakukanlah itu kepada orang lain ${ }^{42}$. Dengan kata lain, inti dari etika global Hans Küng adalah mengasihi Allah dan sesama manusia, seperti mengasihi diri sendiri. Maka, ia akan memerlakukan tidak dengan semena-mena, dan akan memerlakukan manusia secara manusiawi atau memanusiakan manusia menjadi manusia, siapapun dia, tanpa memerhatikan agama, status sosial, suku, ras, budaya. Hal ini ada di dalam semua agama di dunia ini, di dalamnya terdapat perwujudan dari empat perintah kuno yang ditemukan di setiap agama besar, yaitu: 'tidak boleh membunuh, tidak boleh mencuri, tidak boleh berbohong, tidak boleh menyalahgunakan seksual ${ }^{43}$ '’

\section{Prinsip etika global}

Etika global bagi Küng sangat penting untuk tatanan dalam dunia yang penuh dengan kekacauan, sehingga melalui etika global setidaknya perdamaian dapat dijaga dan ada tatanan atau aturan yang membentengi dunia, yaitu negara-negara.

Prinsip-prinsip etika global Kung tersebut adalah"4: 1) sebagai prinsip tatanan global atau dunia yang baru. Dunia memiliki banyak masalah, kepentingan ekonomi, kekacauan, peperangan, membutuhkan suatu pengikat untuk memagari, sehingga manusia (negara-negara) tidak dapat melakukan sesuatu yang hanya menguntungkan dirinya, serta merugikan orang lain. Maka, etika global sebagai etika minimalis sangat dibutuhkan dalam dunia ini. Tujuannya adalah agar ada perdamaian dan ketertiban. Etika global tersebut bukanlah suatu ideologi global atau suatu penyatuan semua agama yang melampaui semua agama, dan juga bukanlah untuk mendominasi satu agama dengan agama yang lain. Akan
${ }^{42}$ Ibid., 68.
43 Ibid., 53.
${ }^{44}$ Ibid., 7-31. 
tetapi, maksudnya adalah sebagai suatu konsensus fundamental yang mengikat semua nilai-nilai, suatu standard umum, dan sikap pribadi. Tanpa konsensus ini, maka komunitas akan diancam dengan kekacauan atau kediktatoran dan keputusasaan individu. 2) Prinsip selanjutnya adalah manusia harus diperlakukan secara manusiawi, yang mana ini merupakan prinsip fundamental terhadap kemanusiaan dari etika global.

Oleh sebab itu, empat hal yang harus dilakukan ${ }^{45}$ : a). komitmen terhadap budaya anti kekerasan dan menghormati setiap aspek kehidupan dari manusia: i) manusia, agama, negara tidak boleh mengambil hidup, menyakiti, membunuh orang lain dengan kekerasan dan mengambil nyawa orang lain, sebab ia memiliki hak untuk hidup. Oleh sebab itu harus menghargai hidup orang lain. Hal ini diajarkan oleh semua agama tradisional maupun; ii) tidak ada pertahanan hidup bagi manusia, tanpa perdamaian global; iii) semangat agama yang besar dan etika tradisional adalah menolong orang lain dan tidak dengan kekerasan. Di dalamnya ada toleransi terhadap kaum minoritas dan melindunginya.

3). Kemudian adalah komitmen terhadap solidaritas dan tatanan ekonomi (a just economic order), yaitu ${ }^{46}:$ i) manusia tidak boleh merampas hak milik orang lain. Hal ini merupakan ajaran dari agama besar dan juga etika tradisional, yang mengatakan "You shall not steal", atau dalam kata-kata yang positif "Deal honestly and fairly". Artinya tidak boleh merampas atau mencuri hal milik seseorang ataupun suatu negara tidak boleh mengunakan hak/miliknya tanpa memerhatikan kebutuhan sosial, bumi ataupun orang lain; ii) tidak kedamaian global tanpa keadilan global; iii) semangat kemanusiaannya adalah: 1) semua tujuan ekonomi dan politik adalah untuk kemanusiaan dan bukan untuk kekejaman dan menjajah orang lain maupun bangsa lain dan juga harus mengembangkan semangat untuk berbelas kasihan dengan orang lain dan juga membantunya; 2) mengusahakan dan memertimbangkan saling
45 Ibid.
46 Ibid. 
menghormati dan menghargai orang lain; 3) menilai sikap yang tidak berlebih-lebihan dan kesederhanaan, rendah hati.

4). Komitmen terhadap budaya toleransi dan kehidupan yang benar. Setiap orang harus bertanggungjawab untuk berbicara dan bertindak jujur. Ia tidak boleh berbohong demi keuntungannya sendiri. Orangorang seperti itu harus dihargai dan dihormati. Oleh sebab itu, empat hal yang harus dilakukan, yaitu ${ }^{47}$ : a) di dalam agama besar dan etika tradisional terdapat ajaran, "you shall not lie" atau di dalam istilah positif "speak and act truthfully". Tidak seorang pun baik laki-laki dan perempuan, institusi, negara, gereja atau komunitas religius yang memiliki hak untuk berbohong kepada orang lain; b) tidak ada keadilan global, tanpa kebenaran dan kemanusiaan; c) anak-anak muda harus belajar di rumah atau keluarga, sekolah untuk berpikir dan berbicara jujur; d) spirit manusia yang beragama dan etika tradisional haruslah: i) kebenaran harus diusahakan dalam hubungan dengan sesama daripada sifat yang oppurtunis, ketidakjujuran; ii) harus mencari kejujuran dan ketulusan; iv) harus berani melayani kebenaran dan dapat dipercaya.

4). Komitmen terhadap budaya persamaan hak dan persekutuan antara laki-laki dan perempuan. Semua manusia baik laki-laki dan perempuan harus bertanggungjawab untuk menunjukkan hormat terhadap sesamanya dan pengertian terhadap hubungan ini. Tidak seorang pun yang dapat tunduk terhadap seseorang yang mengeksploitasi secara seksual atau jender, melainkan persekutuan berdasarkan persamaan hak harus dikembangkan. Maka ${ }^{48}$, a) agama besar atau kuno dan etika tradisional mengajarkan "You shall not commit sexual immorality" atau di dalam kata-kata positif "Respect and love one another". Tidak boleh seseorang mengeksploitasi seseorang secara seksual; b) kutukan terhadap eksploitasi seksual dan diskriminasi seksual atau jender, sebagai penghancuran kemanusiaan; c) relasi antara laki-laki

$$
\begin{aligned}
& { }^{47} \text { Ibid., 23-26. } \\
& { }^{48} \text { Ibid., 27-30. }
\end{aligned}
$$


dan perempuan harus berdasarkan kasih dan bukan berdasarkan eksploitasi; e) institusi sosial seperti pernikahan, meskipun berbeda budaya dan agama adalah ditandai dengan kasih, kesetiaan dan komitmen.

5).Transformasi kesadaran dari manusia, agama, bangsa maupun negara. Etika global dapat tercapai, apabila seluruh umat manusia, agama, etnis, bangsa dan negara di dunia sadar bahwa etika global ini penting untuk perdamaian dunia atau tatanan dunia yang lebih baik lagi49. Tanpa kesadaran pribadi, maka etika global ini tidak mungkin untuk dilakukan.

\section{Esensi Etika Global}

Oleh sebab itu, ada beberapa hal penting atau yang menjadi hakikat dalam etika global ini, yaitu ${ }^{50}$ 1) etika ini untuk kebaikan manusia itu sendiri, yaitu untuk kehidupan, kebebasan, martabat atau kehormatan, dan hak manusia; 2) sebagai etika minimalis yang terdapat di dalam semua agama yaitu tidak membunuh, tidak berbohong, tidak mencuri, tidak melakukan imoralitas secara praktis, menghormati orang tua dan mengasihi anak-anak; 3) jalan tengah, yaitu semua agama tidak hanya berbicara mengenai aturan atau hukum, tetapi juga karakter, sikap, nilainilai yang dapat mengarahkan hidup manusia; 4) golden rule, yaitu "apapun yang Anda harapkan dari orang lain, maka lakukanlah itu kepada orang lain" (sudah dijelaskan di atas); 5) motivasi moral, etika global ini menjadi motivasi moral, di mana menjadi gaya hidup dan sikap hidup baru dalam kehidupan beragama dan berbangsa dan bernegara; 6) menjadi tujuan hidup. Inilah yang menjadi tujuan atau gol dari kehidupan manusia dalam melakukan apa saja, khususnya dalam beragama.

${ }^{49}$ Ibid., 7-31.

${ }^{50}$ Hans Küng, Global Responsibility: In Search of a New World Etbic (New York: Crossroad, 1991), 56-60. 


\section{Perjuangan etika global}

Hal yang diperjuangkan dalam etika global dalam dunia ini adalah ${ }^{51}$ : 1) tidak hanya kemerdekaan, tetapi juga keadilan. Hal yang dibutuhkan adalah tatanan dunia sosial, yaitu kesetaraan manusia, tidak membedakan kaya dan miskin, menyediakan lapangan pekerjaan, memerjuangkan hak asasi manusia dan juga melepaskan orang yang tertindas, hidup yang diatur oleh etika dan norma dunia, membantu orang yang miskin dan kelaparan; 2) tidak hanya persamaan, tetapi juga pluralitas. Menghilangkan diskriminasi seperti suku, etnis, ras, agama, bangsa, budaya, sosial. Tidak membedakan dunia maju dan dunia ketiga. Menghilangkan rasa antisemitisme di dalam gereja. Oleh sebab itu, manusia membutuhkan tatanan dunia yang pluralistis; 3) tidak hanya persaudaraan/brotherhood, tetapi juga sisterhood, di mana tidak ada lagi pembedaan antara laki-laki dan perempuan dalam gereja. Memberikan ruang kepada perempuan untuk berkarya. Melepaskan ideologi yang negatif kepada perempuan dan mengakui anugerah dan talenta kepada perempuan dalam gereja. Jadi, manusia pada saat ini membutuhkan tatanan dunia partnership; 4) bukan hanya hidup berdampingan, tetapi juga perdamaian. Dunia pada saat ini membutuhkan perdamaian dan juga jalan damai dalam menyelesaikan konflik. Maka, solidaritas sesama manusia perlu ditingkatkan.

Oleh sebab itu, ideologi perang perlu disingkirkan, dan juga membuang ideologi yang menghina yang ilahi dan juga kemanusiaan. Membuang penyembahan kekuasaan dan juga militarisme. Meninggalkan tindakan yang mengunakan senjata militer, sehingga mengancam hak asasi manusia untuk hidup; 5) tidak hanya produktivitas, tetapi juga solidaritas terhadap lingkungan hidup. Manusia tidak boleh hanya mengeksploitasi alam, tetapi juga harus hidup berdampingan dan juga menjaganya. Oleh sebab itu, manusia harus bersahabat dengan lingkungan alam; 6) tidak hanya toleransi, tetapi juga ekumene. Gereja

${ }^{51}$ Ibid., 67-69. 
harus membuang perpecahan di dalam gereja-gereja. Membuang kecurigaan terhadap sesama gereja. Melupakan kepahitan masa lalu. Membuang intoleransi. Jadi, manusia membutuhkan tatanan ekumene di dalam dunia ini.

Kesadaran akan pentingnya rasa tanggungjawab atas masa depan manusia harus dikembangkan. Ketiadaan etika akan mengakibatkan masalah di dalam dunia ini. Jadi, dunia membutuhkan etika global. Karena, tidak ada kelangsungan hidup, tanpa ada etika dunia/world ethic.

\section{Etika global sebagai tanggungjawab bersama}

Etika global ini merupakan suatu tanggungjawab setiap manusia, bangsa/negara, agama ${ }^{52}$, agar dilakukan di manapun juga, baik itu hubungan antar bangsa, agama, dan yang lainnya: Slogan etika tanggungjawab ini adalah ${ }^{53}$ : 1) sebuah etika tanggungjawab merupakan suatu etika dan watak yang harus dimiliki oleh manusia. Ini merupakan motivasi dari dalam diri manusia, yaitu untuk memerjuangkan keadilan, kasih dan kebenaran; 2) tanggungjawab terhadap sesama manusia/tetangga, lingkungan hidup dan dunia setelah ini; 3) manusia merupakan gol dan kriteria dari etika global. Manusia bukan sebagai alat, tetapi tujuan, yaitu untuk memanusiakan manusia menjadi manusia; 4) etika seharusnya menjadi perhatian utama dari masyarakat umum/pemerintah; 5) tidak ada ketertiban di dunia tanpa adalah etika dunia ini. Slogan ini ini tidak hanya dituntuk kepada orang lain, tetapi juga pertama sekali untuk mengkritisi diri sendiri, kemudian kepada orang lain.

${ }^{52}$ Küng menyatakan bahwa ini merupakan tanggungjawab gereja, sebagai bagian dari kesaksian akan Kristus dan juga sebagai perwujudan dari Kerajaan Allah di bumi ini (Hans Kung, The Church, New York: Sheed and Ward, 1967).

${ }^{53}$ Küng, Global Responsibilit., 56-58. 
Etika global Küng juga memerjuangkan humanisme atau kemanusiaan ${ }^{54}$. Bagi Küng, dasar dari humanisme ini adalah martabat manusia itu sendiri dan ini merupakan hak dasar manusia ${ }^{55}$. Martabat manusia itu adalah hak-haknya sebagai manusia harus diperjuangkan, seperti kemerdekaan, kebebasan untuk hidup, hak beragama, berbicara ${ }^{56}$, pengakuan kesatuan keluarga manusia, yaitu persamaan dan martabat semua laki-laki dan perempuan, pentingnya dan kudusnya individu dan kesadarannya, iman dalam kasih, simpati, tidak mementingkan diri sendiri dan kuasa kebenaran dalam pikiran dan dalam hati lebih besar kuasanya dari pada kebencian, permusuhan dan kepentingan diri sendiri, kewajiban membantu orang yang miskin, tertindas, orang terpinggirkan, dan melawan orang kaya dan penguasa yang menindas orang miskin dan terpinggirkan, serta pengharapan yang dalam atas kemenangan kehendak yang baik ${ }^{57}$.

Hal ini merupakan suatu nilai-nilai universal di seluruh dunia ${ }^{58}$, di mana ini sesuatu yang sangat diiinginkan oleh manusia. Nilai-nilai kemanusiaan atau humanisme ini ada di dalam seluruh agama di dunia ini. Sebab, agama-agama bertujuan untuk melayani kemanusiaan atau humanitas, sehingga manusia dapat menemukan tujuan hidup, kebahagiaan dan eksistensi dirinya menghasilkan buah. Ini terlihat di dalam doktrin, ajaran, etika, iman dan upacara dari agama-agama.

Jadi, kemanusiaan merupakan landasan dan presuposisi dari agama ${ }^{59}$, di mana ini merupakan ciri dan ukuran dari agama sejati atau

54 Aeron F. Sihombing "Menuju Dialog Antar Agama-Agama di Indonesia”, Jurnal Te Deum Vol.1, No.3 Juli-Desember 2013 (Cianjur: STT SAPPI, 2013), 63-81.

${ }^{55}$ Küng, Global Responsibility, 138.

56 Ibid., 89-90.

57 Hans Küng, Theology for the Third Millenium An Ecumenical View (New York: Double, 1988), 243.

${ }^{58}$ Ibid., 240-247.

${ }^{59}$ Ibid., 92. 
agama yang benar, yang memerjuangkan martabat manusia, selain itu adalah agama yang tidak benar dan patut untuk dipertanyakan. Martabat manusia merupakan nilai-nilai minimum dari agama-agama, sehingga agama yang benar harus mewujudkan dan mengkonkretkan humanitas sebagai suatu kewajiban di dalam ibadahnya.

Oleh sebab itu, etika global adalah menghormati humanitas atau bumanum. Sebab, kemanusiaan agama-agama ada dan hadir untuk memerjuangkan dan membebaskan manusia dari penjajahan, penindasan, rasisme. Di samping itu, ini merupakan esensi dari agama yaitu memerjuangkan hak-hak asasi manusia di dunia, secara khusus di Indonesia, misalnya adalah dengan memberikan kebebasan dan jaminan akan beribadah kepada agama-agama yang relatif kecil, seperti Kristen, Ahmadiah, serta kepercayaan lokal di Indonesia. Jika ini dilakukan dan diwujudkan di Indonesia, maka akan terjadi kerukunan dan perdamaian antar umat beragama.

\section{Fondasi etika global}

Dasar atau fondasi dari etika global Küng adalah Yesus Kristus, di mana Yesus mengatakan di dalam perkataan dan perbuatan-Nya bahwa Ia melakukan kehendak Allah di muka bumi ini, yaitu kebaikan manusia/man's well being60. Inilah dasar atau landasan mengapa Yesus datang ke dunia dan tersalib untuk menyelamatkan manusia. Semua ini adalah demi kebaikan, kepentingan, kehormatan manusia, bukan untuk kepentingan Allah.

Oleh sebab itu, manusia (siapapun itu, tanpa memandang suku, ras, agama) harus dihargai dan dihormati, manusia harus diperhatikan, tidak boleh disakiti, dihancurkan, didehumannisasi. Dengan demikian, manusia harus dimanusiakan. Dengan kata lain, humanitas atau sifat kemanusiaan manusia harus diperjuangkan, diperhatikan dan tidak boleh

${ }^{60}$ Hans Küng, On Being A Christian (New York: Double\&Company, 1974), 463-466. 
diabaikan, bahkan ditindas oleh manusia, apalagi oleh orang Kristen. Ia mengatakan bahwa seorang Kristen haruslah manusiawi/humanitas ${ }^{61}$. Apabila seorang Kristen tidak manusiawi/humanitas, maka dapat dikatakan bahwa dia bukanlah seorang Kristen. Erasmus mengatakan bahwa seseorang yang manusiawi belum tentu adalah seorang Kristen, tetapi seorang Kristen haruslah humanitas/manusiawi.

Akan tetapi, humanitas/kemanusiaan orang Kristen bukanlah berpusat pada humanisme. Perbedaannya adalah kalau humanisme, maka humanitas itu berdasarkan pada otonomi manusia, yaitu rasionalitas manusia itu semata. Sementara itu, humanitas/kemanusiaan orang Kristen adalah berpusat pada Yesus Kristus, yang adalah salah satu bagian dari Teosentris yang Trinitarian (atau yang disebut dengan teonomi oleh Kung) ${ }^{62}$. Hal ini dimulai dari iman kepada Yesus Kristus, yang diterima melalui anugerah dari Allah. Maka, Yesus adalah model, contoh, teladan dari seluruh kehidupan orang Kristen. Semua perkataan, ajaran, perbuatan, tindakan dan juga kehidupan Yesus merupakan landasan hidup orang Kristen. Sebab, perkataan, ajaran dan perbuatan atau tindakan Yesus tidak dapat dipisahkan satu dengan yang lain (berbeda dari Marx, Plato, yang sistem filsafatnya atau ajarannya dapat dipisahkan dari orangnya). Mereka adalah suatu kesatuan yang tidak dapat dipisahkan, sebab ajaran atau perkataan Yesus dipraksiskan di dalam tindakan Yesus, sehingga menjadi konkret. Demikian juga dengan tindakan atau perbuatan Yesus, merupakan penjabaran dari perkataan dan ajaran Yesus ${ }^{63}$. Hal ini menunjukkan bahwa Yesus bukan seorang metafisikawan ala Yunani yang sangat menyukai yang abstrak, tetapi pengajaran Yesus adalah konkret dan aplikatif. Tidak boleh juga dilupakan yaitu kehidupan Yesus, baik kelahiran, penderitaan, kematian dan kebangkitan Yesus juga adalah suatu kesatuan yang tidak boleh
${ }^{61}$ Ibid., 249-252.
${ }^{62}$ Ibid., 534-536.
${ }^{63}$ Ibid., 119-153. 
untuk dipisahkan. Ini merupakan bagian penting di dalam kekristenan dan semuanya memiliki makna di dalam kekristenan.

Semua perkataan, ajaran, tindakan/perbuatan dan kehidupan (kelahiran, penderitaan, kematian, kebangkitan) Yesus tersebut adalah: untuk membebaskan manusia dari perbudakan, penindasan (sistem pemerintahan yang menindas), penderitaan, sakit, dosa, kemiskinan secara sosial maupun rohani. Ini adalah isi berita Kerajaan Allah yang diberitakan oleh Yesus di dalam ajaran, perkataan, tindakan/perbuatan dan kehidupan Yesus. Dia datang untuk membebaskan dan memerdekakan manusia. Inilah kehendak Allah yaitu kebaikan/man's well being 64 .

Maka, menjadi seorang Kristen harus mengikuti Yesus Kristus dan melakukan kehendak Allah, yang memerjuangkan kebaikan manusia/man's well being65. Semuanya harus dilakukan berdasarkan kasih, yang dilandasi oleh kasih Allah dan kasih terhadap sesama manusia: tetangga, yaitu orang yang membutuhkan, seperti orang yang miskin, tertindas, menderita. Kasih ini adalah kasih yang tanpa syarat dan kasih yang tidak meminta imbalan atau jasa dari orang yang menerimanya. Oleh sebab itu, ia tidak boleh menyakiti orang lain, sehingga ini merupakan fondasi dari etika global Küng.

Hal inilah yang menjadi presuposisi Küng di dalam mendekati persoalan di dalam masyarakat, yaitu menjadi seorang Kristen, yang humanis/manusiawi. Humanitas/manusiawi ini merupakan dasar di dalam pendekatan terhadap agama-agama atau pluralitas maupun dengan ateisme. Semua agama (agama apapun itu) harus dihargai dan dihormati. Mereka memiliki hak untuk percaya dan memeluk agamanya.

${ }^{64}$ Ibid.

${ }^{65}$ Ibid., 249-273. 


\section{KORELASI ETIKA PERJANJIAN LAMA DAN ETIKA GLOBAL}

Etika Perjanjian Lama dan etika global Küng adalah saling berhubungan dan mendukung satu dengan yang lain. Hal ini terlihat dalam esensi etika dalam Perjanjian Lama adalah dengan melakukan keadilan, yaitu dengan tidak melakukan kekerasan dan penindasan kepada orang lain yaitu orang yang miskin, lemah, anak yatim piatu, janda, budak, orang lain. Mereka harus dibantu, ditolong, dan dihargai sebagai manusia, bahkan sebagai saudara/brother. Misalnya, membebaskan hutang, budak (karena hutang, dan yang lainnya) pada tahun sabbath. Di sisi lain, tidak membungakan uang kepada saudara/sesamanya, bahkan tidak memaksa untuk meminta kembali uang tersebut. Budak juga harus diperlakukan secara manusiawi dengan melepaskan mereka pada tahun sabbath, tidak menghukum dan melindungi mereka pada saat lari dari tuannya. Orang asing juga harus dilindungi dan tidak boleh ditindas. Di samping itu, keadilan dalam Perjanjian Lama harus ditegakkan dalam pengadilan, oleh para hakim, raja, pejabat, iman di Israel.

Demikian juga dengan etika global Küng, yaitu the golden rule nya yaitu tidak boleh melakukan kekerasan dengan orang lain. Apa yang ingin kita lakukan terhadap diri sendiri, demikian jugalah harus dilakukan kepada orang lain. Oleh sebab itu, penindasan terhadap orang lain, bangsa lain, harus dihapuskan dan dilarang. Di samping itu, etika global memerjuangkan kesetaraan manusia, yaitu tidak memandang suku, ras,agama, status sosial, sebab semuanya sama di hadapan Allah. Maka, semua manusia, agama, bangsa harus saling menghormati dan menghargai satu dengan yang lain.

Oleh sebab itu, titik temu atau perjumpaan etika Perjanjian Lama dan etika global adalah di dalam konsep keadilan, di mana keadilan merupakan esensi dari setiap peraturan dalam Perjanjian Lama dan ini juga yang diperjuangkan oleh etika global Küng. Ini merupakan salah 
satu bagian nilai dari Kerajaan Allah yang harus ditegakkan di bumi ini; kemudian adalah hak asasi manusia, di mana manusia memiliki hak untuk hidup dengan layak, tidak boleh ditindas, hak bersuara, beragama, hak untuk dihargai dan dihormati; etika selanjutnya adalah kesetaraan atau kesederajatan sesama manusia, sebab manusia adalah gambar dan rupa Allah. Oleh sebab itu, manusia sama di hadapan Allah.

Baik etika Perjanjian Lama dan etika global sangat memerhatikan kesejahteraan manusia, seperti peraturan-peraturan dalam Perjanjian Lama untuk mengurangi kemiskinan, penindasan, dalam kehidupan umat Israel. Misalnya dengan mengambil semua hasil panen di ladang, dengan meninggal bagian pinggir ladang, untuk diberikan kepada orang miskin, orang asing, yatim, janda, bahkan pada tahun sabbath ladang dibiarkan tumbuh sendiri, di mana hasilnya untuk orang lain. Demikian juga yang dilakukan oleh Yesus, pelayanan-Nya adalah untuk kesejahteraan manusia, misalnya dengan memberikan 5000 orang; memerhatikan orang miskin, menyembuhkan orang sakit, lumpuh, buta dan berbagai macam penyakit yang lainnya.

Solidaritas sesama manusia, secara khususnya adalah orang-orang miskin dan tertindas merupakan bagian yang sangat penting dalam etika Perjanjian Lama dan etika global. Mereka harus dibebaskan dan dilepaskan dari belenggu penindasan dan kemiskinan tersebut. Hal ini bukan hanya teori, melainkan harus diwujudkan atau dikonkretkan, sebab ini merupakan esensi dari paradigma Perjanjian Lama maupun Perjanjian Baru ${ }^{66}$. Hal ini bukan hanya dipercayai, tetapi juga dilakukan atau harus ada aksi. Melalui hal inilah, ada pembebasan orang-orang yang miskin dan tertindas

Jadi, etika Perjanjian Lama dan etika global Küng puncaknya adalah bagaimana memanusiakan manusia menjadi manusia. Dengan kata lain, memerhatikan sisi kemanusiaan, yaitu dengan kesetaraan manusia,

${ }^{66}$ Epzstein, Social Justice, 95-100. 
meningkatkan kesejahteraan manusia, memelihara hak asasi manusia, melepaskan manusia dari penderitaan, penindasan, menjaga dan memelihara persaudaraan dan solidaritas sesama manusia. Hal inilah yang menjadi esensi dari Alkitab dan juga salah satu nilai dari Kerajaan Allah dalam Yesus Kristus yang dinyatakan dalam Perjanjian Baru.

\section{APLIKASI ETIKA PERJANJIAN LAMA DAN ETIKA GLOBAL: TUGAS GEREJA DALAM PLURALITAS DI INDONESIA}

\section{Memerjuangkan hak asasi manusia}

Tugas gereja adalah bagaimana melakukan apa yang perintahkan oleh Allah dalam Alkitab yaitu memerjuangkan hak asasi manusia. Gereja harus berani membela orang yang tidak mampu dan tidak memiliki kekuatan untuk memertahankan diri orang yang lemah dan yang tidak memiliki kekuatan hukum. Salah satu contohnya adalah perjuangan Pdt.Josef P. Widyatmadja yang membela para petani yang tanahnya tergusur di Kedungombo, Boyolali, Jawa Tengah ${ }^{67}$.

\section{Memerjuangkan orang yang tertindas}

Tugas gereja selanjutnya harus memerjuangkan orang tertindas, penjajahan akibat dari sistem baik pemerintahan atau apapun yang menindas manusia atau masyarakat, secara khusus di Indonesia. Salah satu yang dapat diperjuangkan gereja adalah dengan membela para pembantu rumah tangga yang bekerja di luar negeri untuk mencari uang, di mana mereka diperkosa, disiksa, ditindas oleh majikannya, bahkan sampai ada yang dihukum mati; memerjuangkan nasib buruh pabrik maupun buruh tani di Indonesia. Mereka harus disadarkan akan nasib dan hak-hak mereka dalam bekerja di pabrik atau perusahaan.

67 Josef P. Widyatmadja, Yesus dan Wong Cilik, Praksis Diakonia Transformatif dan teologi Rakyat di Indonesia (Jakarta: BPK Gunung Mulia, 2010), 48. 


\section{Memerjuangkan kesetaraan suku, ras, etnis, agama}

Negara Indonesia merupakan negara multi etnis, budaya, agama, suku, bahasa. Oleh sebab itu, salah satu persoalan dalam bangsa Indonesia adalah diskriminasi baik agama, dan suku. Salah satu diskriminasi yang masih ada di Indonesia adalah penutupan beberapa gereja di daerah Jawa Barat, secara khusus adalah di Cianjur. Penutupan gereja tersebut adalah dengan alasan tidak memiliki ijin dan warga sekitarnya tidak setuju. Sementara itu, pengurusan ijinnya dipersulit oleh pemerintah setempat. Penutupan gereja ini dilakukan oleh organisasiorganisasi masyarakat, di mana motifnya adalah motif ekonomi, yaitu memeras gereja untuk mencari uang. Apakah gereja-gereja di Indonesia akan berusaha untuk membela dan memerjuangkan gereja, sehingga ia dapat beribadah dengan aman? Oleh sebab itu, solidaritas sesama saudara seiman dalam gereja yaitu untuk saling membantu, menolong gereja-gereja yang bukan satu denominasi perlu untuk ditingkatkan dan diperhatikan untuk memerjuangkan gereja-gereja yang tertindas di sekitarnya.

\section{Memerjuangkan kesejahteraan manusia.}

Gereja tidak hanya memproklamasikan Injil di atas mimbar atau hanya bertugas untuk melayani jemaat di bidang spiritual. Tetapi, aspek ekonomi, fisik, juga perlu untuk diperhatikan dan dilayani oleh gereja terhadap jemaatnya maupun kepada masyarakat, seperti dalam Perjanjian Lama di mana orang miskin sangat diperhatikan. Demikian juga dengan Yesus, Ia menyembuhkan orang sakit, orang buta dan memerhatikan orang miskin. Salah satu tugas gereja adalah bagaimana membantu jemaat yang sedang mengalami kekurangan ekonomi, pengangguran, membantu jemaat yang terjebak hutang kepada rentenir, sehingga ia kehilangan hartanya, membantu dan mengatasi jemaat yang tidak dapat melanjutkan pendidikan dasarnya. Hal ini merupakan bagian dan tugas dari gereja yang diberikan oleh Allah. Semangat persaudaraan dan solidaritas sesama saudara seiman sangat diperlukan untuk meningkatkan 
kesejahteraan jemaat. Di sisi lain, gereja tidak hanya melakukan ini kepada jemaatnya atau orang Kristen, melainkan ia juga harus melakukannya kepada masyarakat di sekitarnya, tanpa memandang agama, suku dan ras.

\section{Memerjuangkan keadilan}

Salah satu bagian terpenting dari etika Alkitab adalah keadilan. Oleh sebab itu, gereja itu sendiri atau orang Kristen harus menegakkan keadilan di dalam tubuhnya sendiri, kemudian di masyarakat di mana ia berada. Hal ini memang memertaruhkan nyawa, sehingga membutuhkan keberanian untuk melakukannya. Salah satunya adalah beberapa gereja tertentu, seorang hamba Tuhan dikontrak oleh gereja, dan setelah selesai kontraknya, ketika majelis jemaatnya kurang suka padanya, maka ia akan selesai melakukan pelayanannya, sehingga gereja sudah hampir mirip dengan perusahaan. Para karyawan gereja, seperti satpam, office boy/cleaning service digaji di bawah standard (UMR). Oleh sebab itu, hal ini merupakan penindasan yang terselubung dalam gereja. Maka, beberapa gereja telah melakukan ketidakadilan di dalam dirinya sendiri.

Jadi, gereja harus mengusahakan dan memerjuangkan keadilan dalam dirinya sendiri, kemudian ia melakukannya di dalam masyarakat sekitarnya, dan di bangsa Indonesia ini. Keadilan dapat ditegakkan dengan penegakan hukum dan mematuhi peraturan yang ada, baik dalam Alkitab, maupun undang-undang. Tugas gereja adalah menyerukan dan menegakkan hal tersebut.

\section{KESIMPULAN}

Etika Perjanjian Lama dan etika global Hans Küng adalah saling berhubungan satu dengan yang lain dan tidak saling bertentangan. Sebab fondasi atau dasar dari etika global (dari Peranjian Baru) adalah berasal dari Perjanjian Lama. Etika Perjanjian Lama dan etika global adalah sama-sama memerjuangkan dan menegakkan keadilan orang-orang yang miskin, tertindas, orang yang terpinggirkan, anak yatim piatu, janda, 


\section{2 | RELASI ETIKA PL DENGAN ETIKA GLOBAL HANS KUNG}

orang asing/imigran (dalam Perjanjian Lama), menyuarakan penegakan keadilan dalam hukum, memerjuangkan hak asasi manusia yang telah ditindas dan dirampas oleh sistem ataupun oleh para penguasa dan orang-orang tertentu, melawan diskriminasi sosial, jender, agama.

Oleh sebab itu, esensi dari etika Perjanjian Lama dan etika global adalah memanusiakan manusia menjadi manusia. Bagaimana manusia yang tertindas karena haknya telah dirampas dilepaskan dari penindasan tersebut, sehingga hak asasinya dapat dikembalikan lagi. Bagaimana manusia yang diperlakukan sebagai hewan, dikembalikan lagi martabatnya sebagai manusia yang adalah gambar dan rupa Allah. Dengan demikian, kesejahteraan manusia baik secara fisik dan spiritual diusahakan dan diperjuangkan, sehingga kehendak Allah yaitu Kerajaan Allah di muka bumi akan hadir dan dinyatakan di bumi Indonesia ini. Semua dilakukan karena kasih terhadap Allah dan kasih terhadap sesama manusia. 